\title{
A Review: The Wettability and Oxidation Resistance of Sn-Zn-X Lead-Free Solder Joints
}

\author{
L. Sun \\ School of Mechanical and Electrical Eng ineering \\ Jiangsu Normal University \\ Xuzhou, China
}

\author{
L. Zhang \\ School of Mechanical and Electrical Eng ineering \\ Jiangsu Normal University \\ Xuzhou, China
}

\begin{abstract}
With the development of lead-free solders, $\mathrm{Sn}-\mathrm{Zn}$ solder was attracted increasing attention due to its low melting point, cost saving and excellent mechanical properties. However, there are many problems need to resolved, such as poor wettability and oxidation resistance. In order to overcome these shortcomings, more recent studies on $\mathrm{Sn}-\mathrm{Zn}$ solder have proposed strategies aimed at obtaining a good wettability and solderability by adding a third or fourth elements, such as $\mathrm{In}, \mathrm{Ga}, \mathrm{P}, \mathrm{Bi}, \mathrm{Ni}, \mathrm{Cr}, \mathrm{Ag}, \mathrm{Cu}$, Al and rare earth. This work summarizes the effects of alloying elements to the wettability and oxidation resistance of $\mathrm{Sn}-\mathrm{Zn}$ lead-free solders.
\end{abstract}

Keywords-lead-free solders; alloying elements; wettability; oxidation resistance

\section{INTRODUCTION}

For a long time, the traditional $\mathrm{Sn}-\mathrm{Pb}$ solder has been widely used in the electronic devices. Due to the increasing environment and toxic concerns, governments of many countries have established laws to prohibit the use of $\mathrm{Pb}$ from electronic packaging [1-3]. Today, studies on the lead-free solder have made breakthrough progress, Sn-Ag, Sn-Cu, Sn-Zn and $\mathrm{Sn}-\mathrm{Ag}-\mathrm{Cu}$ solders have been developed. Among series of lead-free solders, $\mathrm{Sn}$-Zn solder was highly recommended as the promising lead-free solder of the next generation, owing to its favorable melt temperature, low cost and excellent mechanical properties [4,5]. However, because the high activity of $\mathrm{Zn}$, the wettability and oxidation resistance of the $\mathrm{Sn}-\mathrm{Zn}$ alloys are poor, which is a major obstacle to its application [6]. In order to overcome these drawbacks, two methods are taken. One is to develop a new kind of flux which is suited to lead-free solder and the other is to add alloying elements into the $\mathrm{Sn}-\mathrm{Zn}$ solder.

In this paper, we summarize the development of $\mathrm{Sn}-\mathrm{Zn}$ solders, and analyze the effects of alloying elements on wettability and oxidation resistance.

\section{WETTABILITY}

Wettability of solder can be defined as the ability of the molten solder to spread over on a substrate during the reflow process [7]. The better wettability is to evaluate the performance of important indicator. For $\mathrm{Sn}-\mathrm{Pb}$ solder, due to the existence of $\mathrm{Pb}$, the solder alloy owns better wettability. But for lead-free solders, the wettability may be dropped obviously due to the replacement of $\mathrm{Pb}$. Hence, adding alloying elements is an effective method to improve the wettability of Sn-Zn solder alloy.
The addition of alloying elements can be classified as follows:

(i) Add surface-active elements, which can easily accumulate at the solder interface in the molten state.

(ii) Add a large amount of low-active elements to reduce the activity of $\mathrm{Zn}$.

(iii) Add more reactive than $\mathrm{Zn}$ elements, using oxide film that is preferentially formed on the surface of $\mathrm{Zn}$, which can improve the wettability.

The addition of $5 \% \sim 10 \%$ In into $\mathrm{Sn}-9 \mathrm{Zn}$ solder can improve the wettability [8]. The researcher has attributed to solder flux. Yu et al. [9] has also confirmed it. Fima et al. [10] has reported the effect of $0.5 \% \sim 1.5 \%$ In on $\mathrm{Sn}-\mathrm{Zn}$ solder under Ar protective atmosphere and found that the Ar atmosphere can better decrease the surface tension and improve the wettability. $\mathrm{Ga}$ was incorporated into $\mathrm{Sn}-9 \mathrm{Zn}$ solder, which can significantly change the wettability and optimal content was about $0.5 \%$ [11]. Due to the surface-active, Ga would accumulate at solder interface in the melting state then the surface tension of the liquid solder was decreased [12]. The similar phenomenon can be found for $\mathrm{P}$ addition into $\mathrm{Sn}-\mathrm{Zn}$ solders [13]. Zhou et al. [14] confirmed that the addition of Bi to the $\mathrm{Sn}-\mathrm{Zn}$ solder decreases surface tension of the liquid solder, and suppose it is effective to enhance the wettability. The effect of Ni addition to Sn-9Zn lead-free solder on the wettability of aluminum and copper base metal was studied by Huang et al. [15]. It is found that the wettability of Sn-9Zn-xNi solders on Al substrate was much better than on copper substrate. In addition, with increasing of $\mathrm{Ni}$ content, the wettability on copper substrate was slightly enhanced but became worse on Al substrate. Due to the high mutual solubility $\mathrm{Al}$ and $\mathrm{Zn}, \mathrm{Al}$ atoms can dis solve from the substrate into $\mathrm{Sn}-\mathrm{Zn}$ based solders during reflow, to form Al-Zn solid solution during solidification. Chen et al. [16] studied the effect of $\mathrm{Cr}$ on the wettability of $\mathrm{Sn}-9 \mathrm{Zn}$ solder compared with $\mathrm{Sn}-37 \mathrm{~Pb}$ and $\mathrm{Sn}-3.5 \mathrm{Ag}-0.75 \mathrm{Cu}$. It is indicated that the wettability of $\mathrm{Sn}-9 \mathrm{Zn}-\mathrm{xCr}$ solder is poorer than both solders. However, adding $\mathrm{Cr}$ element can slightly improve the wettability of Sn-9Zn solder alloy. The addition of trace amount of $\mathrm{Ag}$ into $\mathrm{Sn}-9 \mathrm{Zn}$ solder can't obviously change the wettability [17]. With the $0.5 \%$ and $1.0 \%$ addition, the wetting angle is slightly lower. With the Ag addition concentration increasing, the wetting angle increases. The reason could attributed to $\mathrm{Sn}-\mathrm{Zn}-\mathrm{xAg}$ solder has better oxidation resistance 
than $\mathrm{Sn}-\mathrm{Zn}$ solder, but when the Ag content exceed a certain, the liquidus temperature increased [18], and the fluidity of the solder decreases with the same soldering temperature. So the wetting angle increases slightly. Yu et al. [19] found that the addition of $\mathrm{Cu}$ can alter the wettability of $\mathrm{Sn}-9 \mathrm{Zn}$ solder. Results show that the wetting angle of $\mathrm{Sn}-9 \mathrm{Zn}$ is $120^{\circ}$ while that of $\mathrm{Sn}-9 \mathrm{Zn}-10 \mathrm{Cu}$ is about $54^{\circ}$. Fima et al. [20] has also investigated the effect of $\mathrm{Cu}$ on $\mathrm{Sn}-8.8 \mathrm{Zn}$ solder, the soldering temperature was $250^{\circ}$ Cand ALU33®flux was used. It is found that the wetting angle of $\mathrm{Sn}-8.8 \mathrm{Zn}$ is about $42^{\circ}$, with $0.5 \% \mathrm{Cu}$ addition, the wetting angle was decreased to about $32^{\circ}$. Some researchers have proposed the ideas that through adding more active Al to inhibit oxidation of $\mathrm{Zn}$ then improve the wettability of Sn-Zn lead-free solder. But according to the existing literature, we find that researchers have different views on improvement the wettability of $\mathrm{Sn}-\mathrm{Zn}$ solder with the addition of Al. Chen et al. [21] has found that adding Al may deteriorate the wettability of the solder. Huang et al. [22] proposed that adding $\mathrm{Al}$ can no signification change the wettability of $\mathrm{Sn}-\mathrm{Zn}$ solder on copper substrate. However, Chen et al. studied the effect of Al under N2 protective atmosphere and $\mathrm{ZnCl} 2+\mathrm{NH} 4 \mathrm{Cl}$ flu $\mathrm{x}$ as well asno-cleaningflux were used, the wettability of solder was extremely improved [23]. Comprehensive results of the study, we can find that only a small amount of Al can show this enhancement effect. When the addition is excessive, the negative effect can be found obviously.

Trace amount of RE elements ( $\mathrm{Ce}$ and $\mathrm{La}$ ), can reduce the surface tension of Sn-9Zn. When the RE content is 0.05 and $0.1 \%$, the wettability is greatly improved with the RA flux [24]. The addition of Er into Sn-Zn was investigated by Zhang et al. [25]. When the addition of Er was $0.08 \%$, the spreading area gave an 19.1\% increase (Fig.1). Ce [26], La [27], Nd [28] and $\operatorname{Pr}$ [29] can also improve the wettability of $\mathrm{Sn}-\mathrm{Zn}$ solders because of the lower surface tension caused by rare earth. Adding a proper amount of rare earth $\mathrm{Pr}$ and $\mathrm{Nd}$ to the Sn-9Zn-0.5Ga solders were studies by Xue et al. [30, 31]. With the addition of $0.08 \%$ Pr or $0.1 \% \mathrm{Nd}$ can significantly improve the wettability of the solder. It is concluded that the rare earth ele ments can improve the wettability of $\mathrm{Sn}-\mathrm{Zn}$ solder, only the optimal contents are different for different elements.

\section{OXIDATION RESIST ANCE}

The poor oxidation resistance of the $\mathrm{Sn}-\mathrm{Zn}$ solder is one of the most factors to hinder its development. Due to the existence of mass $\mathrm{Zn}$ element, the $\mathrm{Sn}-\mathrm{Zn}$ solder is easily oxidized (Table 1), worsened the wettability of solder during soldering. Therefore, it is no doubt that the key issue is improving oxidation resistance of $\mathrm{Sn}-\mathrm{Zn}$ solder.

\section{TABLE I. THE PARTIAL PRESSURE'S DAT A OF COMMON SOLDER'S} OXIDE[32].

\begin{tabular}{ll}
\hline $\mathrm{Bi}_{2} \mathrm{O}_{3} \mathrm{In}_{2} \mathrm{O}_{3} \mathrm{SnO}_{2} \mathrm{PbOZnOCuO}$ \\
\hline $298 \mathrm{~K}$ & $9.0 \times 10^{-39} 5.2 \times 10^{-39} 6.9 \times 10^{-92} 7.0 \times 10^{-67} 2.3 \times 10^{-112}$ \\
$400 \mathrm{~K}$ & $1.4 \times 10^{-41} 4.4 \times 10^{-50} 6.5 \times 10^{-66} 2.2 \times 10^{-47} 2.3 \times 10^{-82} 6.5 \times 10^{-32}$ \\
$500 \mathrm{~K}$ & $1.5 \times 10^{-31} 2.1 \times 10^{-38} 8.9 \times 10^{-57} 5.9 \times 10^{-38} 4.6 \times 10^{-63} 6.8 \times 10^{-24}$ \\
$600 \mathrm{~K}$ & $8.6 \times 10^{-35} 1.4 \times 10^{-35} 1.5 \times 10^{-40} 1.8 \times 10^{-28} 5.4 \times 10^{-51} 2.0 \times 10^{-18}$ \\
\hline Oxidation resistance of Sn-9Zn-xGa solder was tested by \\
means of thermal gravimetric analysis (TGA) method by Chen
\end{tabular}

et al. [11]. Fig. 2 shows that the oxidation resistance is enhanced with the addition of $0.5 \% \mathrm{Ga}$. The addition of $\mathrm{Ag}$ can improve the oxidation of the solder, and $\mathrm{Sn}-9 \mathrm{Zn}-0.3 \mathrm{Ag}$ solder exhibits much lower mass grain than $\mathrm{Sn}-9 \mathrm{Zn}$ in the liquid state at $245^{\circ} \mathrm{C}$ [33]. Lee et al. [34] reported the oxidation behavior of $\mathrm{Sn}-9 \mathrm{Zn}-\mathrm{xAg}$ and $\mathrm{Sn}-9 \mathrm{Zn}-\mathrm{xCu}$ solders during $85^{\circ} \mathrm{C} / 85 \%$ relative humidity $(\mathrm{RH})$ exposure. It is found that the addition of $\mathrm{Ag}$ or $\mathrm{Cu}$ can effectively improve the oxidation resistance, as compared with the $\mathrm{Sn}-\mathrm{Zn}$ and $\mathrm{Sn}-\mathrm{Zn}$-Bi solders. Chang et al. [35] studied the effect of Ag and In addition on the oxidation resistance of Sn-9Zn solders and found that both $\mathrm{Sn}-9 \mathrm{Zn}-0.5 \mathrm{Ag}$ and $\mathrm{Sn}-9 \mathrm{Zn}-0.5 \mathrm{Ag}-1 \mathrm{In}$ solders have a higher oxidation resistance than that of $\mathrm{Sn}-9 \mathrm{Zn}$ solder. Chen et al. [16] demonstrated that the oxidation resistance of $\mathrm{Sn}-\mathrm{Zn}$ solders can be improved with the addition of $\mathrm{Cr}$, which can be attributed to segregation $\mathrm{Cr}$ in the sub-surface layer of $\mathrm{Sn}-\mathrm{Zn}$-xCr solder to prevent further oxidation. Adding Al element can obviously improve the oxidation resistance, however, an excessive amount of $\mathrm{Al}$ addition will form thick film and deteriorate the wettability of $\mathrm{Sn}-\mathrm{Zn}$ solder [36].

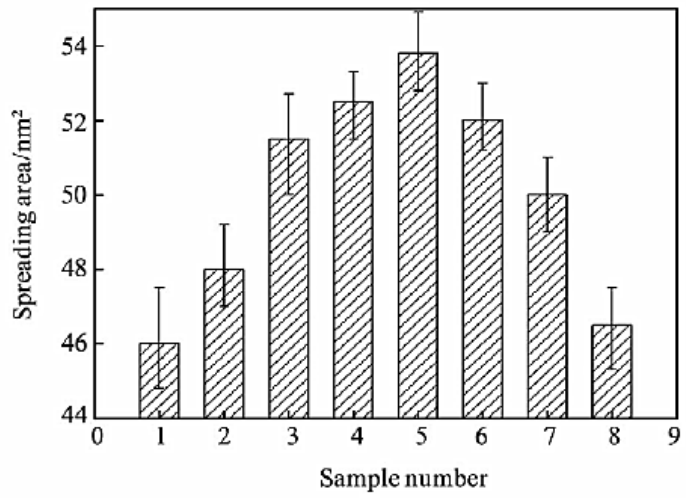

FIGURE I. SPREADINGAREA OF SN-9ZN-XER [25].

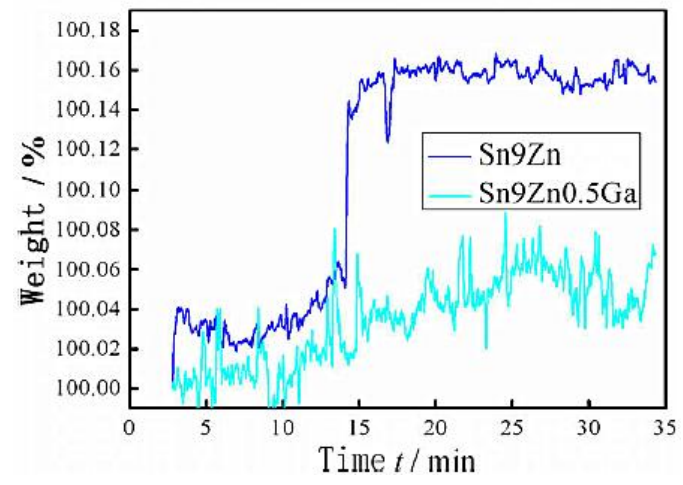

FIGURE II. TGA RESULT S OF SN-9ZN-0.5GA SOLDER COMPARED WITHTHAT OF SN-9ZN SOLDER AT $235^{\circ} \mathrm{C}$ [11].

\section{CONCLUSIONS}

To conclude this review, we can find that the addition of surface-active elements ( $\mathrm{Ga}, \mathrm{P}, \mathrm{Bi}, \mathrm{Ni}$, and $\mathrm{Cr}$ ) can improve the wettability of $\mathrm{Sn}-\mathrm{Zn}$ solder. But when the additives are more than optimal content, the wettability of solder becomes stable, so it is difficult to improve the wettability greatly. The addition of In element can decrease the melting point of the Sn-Zn-In solder and enhances the wettability of the lead-free solder, but the In is very expensive, the addition of In can increase the cost 
of lead-free solders.Adding $\mathrm{Ag}$ can enhance the wettability. The addition of Al element can effectively enhance the oxidation resistance, but just only a small amount of $\mathrm{Al}$ addition can improve the wettability. Moreover, the addition of rare earth elements show the most obvious improvement of wettability, however, rare earth elements may worsen the oxidation resistance, because rare earth is more reactive than Zn.

In a word, adding alloy elements are difficult to significantly improve the wettability and oxidation resistance of $\mathrm{Sn}-\mathrm{Zn}$ solders. However, we find a great enhancement effect on the wettability of the flux, so the development of flux for $\mathrm{Sn}-\mathrm{Zn}$ solder may be the main aspect of future research.

\section{ACKNOWLEDGEMENT S}

This work was supported by the National Natural Science Foundation of China (No. 51475220), the Natural Science Foundation of Jiangsu Province (BK2012144) and the Natural Science Foundation of the Higher Education Institutions of Jiangsu Province (12KJB460005).

\section{REFERENCES}

[1] L. Zhang, K.N. Tu, Structure and properties of lead-free solders bearing micro and nanoparties, Mater. Sci. Eng., R. 82 (2014) 1-32.

[2] A. Fawzy, S.A. Fayek, M. Sobhy, E. Nassr, M.M. Mousa, G Saad,Tensile creep characteristics of Sn-3.5Ag-0.5Cu (SAC355) solder reinforced with nano-metric $\mathrm{ZnO}$ particles,Mater. Sci. Eng., A. 603 (2014) $1-10$.

[3] L. Zhang, J.G Han, Y.H. Guo, L. Sun, Properties and microstructures of $\mathrm{SnAgCu}-\mathrm{xEu}$ alloys for concentrator silicon solar cells solder layer, Sol.Energy Mater. Sol.Cells.130 (2014) 397-400.

[4] L.R. Garcia, L.C. Peixoto, W.R. Osório, A. Garcia, Globular-to-needle Zn-rich phase transition during transient solidification of a eutectic Sn-9\%Zn solder alloy, Mater.Lett.63 (2009)1314-1316.

[5] W.R. Osório, L.C. Peixoto, L.R. Garcia, N. Mangelinck-Noël, A. Garcia, Microstructure and mechanical properties of $\mathrm{Sn}-\mathrm{Bi}, \mathrm{Sn}-\mathrm{Ag}$ and $\mathrm{Sn}-\mathrm{Zn}$ lead-free solder alloys, J. Alloys Compd.572 (2013) 97-106.

[6] J.X. Liang, T.B. Luo, A.M. Hu, M. Li, Formation and growth of interfacial intermetallic layers of $\mathrm{Sn}-8 \mathrm{Zn}-3 \mathrm{Bi}-0.3 \mathrm{Cr}$ on $\mathrm{Cu}, \mathrm{Ni}$ and $\mathrm{Ni}-\mathrm{W}$ substrates,Microelect ron. Reliab.54 (2014) 245-251.

[7] S.K. Ghosh, A.S.M.A. Haseeb, A. Afifi, Effects of metallic nanoparticle doped flux on interfacial intermetallic compounds between $\mathrm{Sn}-3.0 \mathrm{Ag}-0.5 \mathrm{Cu}$ and copper substrate, 15thElectronics Packaging Technology Conference.(2013).

[8] M. McCormack, S. Jin, H.S. Chen, D.A. Machusak, New lead-free, Sn-Zn-In solder alloys, J. Electron.Mater.23 (1994) 687-690.

[9] S.P. Yu, C.L. Liao, M.H. Hon, The effects of flux on the wetting characteristics of near-eutectic $\mathrm{Sn}-\mathrm{Zn}$-In solder on Cu substrate, J. Mater. Sci. 35 (2000) 4217-4224.

[10] P. Fima, T. Gancarz, J. Pstruś, A. Sypień, Wetting of Sn-Zn-xIn ( $\mathrm{x}=0.5$, $1.0,1.5 \mathrm{wt} \%$ ) Alloys on $\mathrm{Cu}$ and Ni Substrates, J. Mater.Eng. Perform.21 (2012) 595-598.

[11] W.X. Chen, S.B. Xue, H. Wang, Wetting properties and interfacial microstructures of $\mathrm{Sn}-\mathrm{Zn}$-xGa solders on $\mathrm{Cu}$ substrate, Mater. Des.31 (2010) 2196-2200.

[12] D.X. Luo, S.B. Xue, Z.Q. Li, Effects of Ga addition on microstructure and properties of $\mathrm{Sn}-0.5 \mathrm{Ag}-0.7 \mathrm{Cu}$ solder, J. Mater. Sci.-Mater.Electron. 25 (2014) 3566-3571.

[13] H.Z. Huang, X.Q. Wei, D.Q. Tan, L. Zhou, Effects of phosphorus addition on the properties of Sn-9Zn lead-free solder alloy, Int. J. Min. MetMater.20 (2013) 563-567.

[14] J. Zhou, Y.S. Sun, F. Xue, Properties of low melting point Sn-Zn-Bi solders, J. Alloys Compd.397 (2005) 260-264.
[15] M.L. Huang, N. Kang, Q. Zhou, YZ. Huang, Effect of Ni Content on Mechanical Properties and Corrosion Behavior of $\mathrm{A} / \mathrm{Sn}-9 \mathrm{Zn}-\mathrm{xNi} / \mathrm{Cu}$ Joints, J. Mater. Sci. Technol.28 (2012) 844-852.

[16] X. Chen, A.M. Hu, M. Li, D.L Mao, Study on the properties of Sn-9Zn-xCr lead-freesolder, J. AlloysCompd.460 (2008) 478-484.

[17] K. Berent, P. Fima, T. Ganacarz, J. Pstruś, Wetting and Microstructure Evolution of the $\mathrm{Sn}-\mathrm{Zn}-\mathrm{Ag} / \mathrm{Cu}$ Interface, J. Mater.Eng. Perform. 23(2014) $1630-1633$.

[18] K.L. Lin, C.L. Shih, Microstructure and Thermal Behavior of Sn-Zn-Ag Solders, J. Electron. Mater.32 (2003) 1496-1500.

[19] D.Q. Yu, H.P. Xie, L. Wang, Investigation of interfacial microstructure and wetting property of newly developed $\mathrm{Sn}-\mathrm{Zn}-\mathrm{Cu}$ solders with $\mathrm{Cu}$ substrate, J. AlloysCompd.385 (2004) 119-125.

[20] P. Fima, J. Pstruś, T. Gancarz, Wetting and Interfacial Chemistry of $\mathrm{SnZnCu}$ Alloys with $\mathrm{Cu}$ and $\mathrm{Al}$ Substrates, J. Mater.Eng. Perform.23 (2014) 1530-1535.

[21] X. Chen, M. Li, X.X. Ren, A.M. Hu, D.L. Mao, Effect of Small Additions of Alloying Elements on the Properties of Sn-Zn Eutectic Alloy, J. Electron. Mater.35 (2006) 1734-1739.

[22] M.L. Huang, X.L. Hou, N. Kang, Y.C. Yang, Microstructure and interfacial reaction of $\mathrm{Sn}-\mathrm{Zn}-\mathrm{x}(\mathrm{Al}, \mathrm{Ag})$ near-eutectic solders on $\mathrm{Al}$ and Cu substrates, J. Mater.Sci. - Mater.Electron. 25 (2014)2311-2319.

[23] L. Zhang, S.B. Xue, L.L. Gao, Z. Sheng, H. Ye, Z.X. Xiao, G Zeng, Y Chen, S.L. Yu, Development of Sn-Zn lead-free solders bearing alloying elements, J. Mater. Sci. - Mater.Electron.21 (2010) 1-15.

[24] C.M.L. Wu, C.M.T. Law, D.Q. Yu, L. Wang,The Wettability and Microstructure of Sn-Zn-RE Alloys, J. Electron.Mater.32 (2003) 63-69.

[25] L. Zhang, J.H. Cui, J.G Han, Y.H. Guo, C.W. He, Microstructures and properties of SnZn-xEr lead-free solders, J. Rare.Earth.30 (2012) 790-793.

[26] Y.H. Hu, S.B. Xue,W.X. Chen, H. Wang, Analysis of microstructure and properties of Sn-9Zn-xCe solder, Trans. China Weld.Inst.31 (2010) 77-80.

[27] Z.A. Li, A. Mikula, Z.Y. Qiao, Surface Properties of the Sn-9Zn Alloy with the Trace Addition of Lanthanum,Monatsh. Chem.136 (2005) $1835-1840$.

[28] Y.H. Hu, S.B. Xue, H. Wang, H. Ye, Z.X. Xiao, L.L. Gao, Effects of rare earth element $\mathrm{Nd}$ on the solderability and microstructure of $\mathrm{Sn}-\mathrm{Zn}$ lead-free solder, J. Mater. Sci. - Mater.Electron.22 (2011) 481-487.

[29] Z.X. Xiao, S.B. Xue, Y.H. Hu, H. Ye, L.L.Gao, H. Wang, Properties and microstructure of Sn-9Zn lead-free solder alloy bearing Pr, J. Mater. Sci. - Mater.Electron.22 (2011)659-665.

[30] H. Ye, S.B. Xue, J.D. Luo, Y. Li, Properties and interfacial microstructure of $\mathrm{Sn}-\mathrm{Zn}-\mathrm{Ga}$ solder joint with rare earth $\mathrm{Pr}$ addition, Mater. Des.46 (2013) 816-823.

[31] D.X. Luo, P. Xue, S.B. Xue, Y.H. Hu, Microstructures and properties of Sn-Zn-Ga lead-free solder with rare earth Nd addition, Trans. China Weld. Inst.34 (2013) 57-60.

[32] M. Abtew, G Selvaduray, Lead-free Solders in Microelectronics, Mater Sci. Eng., R.27 (2000) 95-141.

[33] W.X. Chen, S.B. Xue, H. Wang, Y.H. Hu, Effects of Ag on Properties of Sn-9Zn Lead-Free Solder, Rare Metal. Mat. Eng.39 (2010) 1702-1706.

[34] J.E. Lee, K.S. Kim, M. Inoue, J.X. Jiang, K. Suganuma, Effects of Ag and $\mathrm{Cu}$ addition on microstruct ural properties and oxidation resistance of Sn-Zn eutectic alloy, J. AlloysCompd.454 (2008) 310-320.

[35] T.C. Chang, J.W. Wang, M.C. Wang, M.H. Hon,Solderability of Sn-9Zn-0.5Ag-1In lead-free solder on $\mathrm{Cu}$ substrate: Part 1. Thermal properties, microstructure, corrosion and oxidation resistance, $\mathrm{J}$ AlloysCompd.422 (2006) 239-243.

[36] H. Wang, S.B. Xue, W.X. Chen, Effects of Al, Ga, and Ag on the surface properties and wetting reactions of Sn-9Zn-X solders, China Weld.18 (2009) 57-61. 